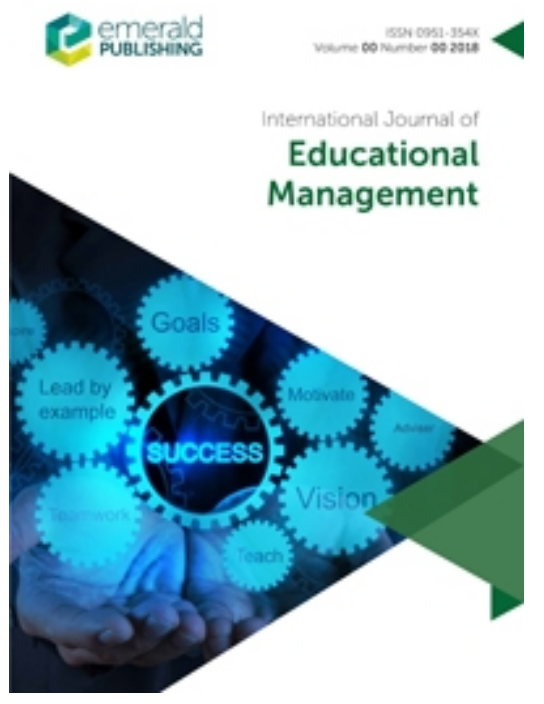

The student as customer and quality in higher education

\begin{tabular}{|r|l|}
\hline Journal: & International Journal of Educational Management \\
\hline Manuscript ID & IJEM-03-2019-0093.R2 \\
\hline Manuscript Type: & Original Article \\
\hline Keywords: & $\begin{array}{l}\text { quality, quality assurance, student as customer, business education, } \\
\text { higher education quality }\end{array}$ \\
\hline \multicolumn{2}{|l}{} \\
\hline
\end{tabular}




\title{
The student as customer and quality in higher education
}

\begin{abstract}
This paper explores some management concepts and how applying these concepts from business to higher education can be problematic, let alone incompatible, particularly in relation to measuring quality in higher education. A number of compelling reasons for this are explored. It discusses that the current bases for perceiving quality such as meeting customer expectations, satisfying the customer, ensuring quality control, meeting standards and assessing the costs associated with poor quality are in disagreement with the principal aims and measures of quality in higher education. Some considerations for understanding quality in higher education are proposed such as when thinking about quality of teaching, quality of programs and quality of the student experience. These considerations aim to refocus education to centre on the student as a learner and an active participant in the learning process.
\end{abstract}

Keywords: student as customer, quality, quality assurance, models, business, business education 


\section{Introduction}

Over the past decades, the increasing interest in quality in higher education has led to higher education and higher education policy being scrutinised (e.g. Tight, 2013). These policy developments include: 1) increased focus on the quality of teaching and learning and the student experience; 2) changes in the funding of higher education; 3) changes in the costs of participating in higher education; 4) increased pressure from accreditation, quality agencies, government regulation, and professional bodies to maintain quality; 5) establishment of quality frameworks in higher education, including setting minimum quality threshold standards for various levels of study; 6) increased pressure from employers for universities to provide quality graduates that meet the demands of future work, including graduates possessing work-ready skills; and 7) an acknowledgement that there are new methods of delivery thus providing an increase in how delivery methods are evaluated. Such developments have been felt in many countries (Guilbault 2016a; Woodall, Hiller \& Resnick 2014a) as quality is subjectively applied based on the context. 'Quality' in higher education is suggested by the UK Quality Assurance Agency (QAA) as "a way of describing how well the learning opportunities available to students help them to achieve their award. It is about making sure that appropriate and effective teaching, support, assessment and learning opportunities are provided for them” (University of Glasgow, 2013, p.3). This definition suggests that quality is a subjective concept to define, even for QAA, which makes communicating it to students difficult.

Using product-based quality indicators will not apply neatly in an educational setting (Lomas 2007; Ng \& Forbes 2009; Watjatrakul 2014; Woodall, Hiller \& Resnick 2014b). This has to do particularly with the intangibility of the benefit of a degree or award (Ng \& Forbes 2009; Ogunnaike, Tairat \& Emmanuel 2014). While it is true that there are aspects of the student 
experience that can be measured using quality indicators (e.g., sufficiency of learning resources, the design of a classroom, achievement of learning outcomes), these aspects sit only at the periphery of a bigger quality issue (McCulloch, 2009; Tight, 2013). When speaking of quality, contemporary ideologies, metaphors of the student as customer and the contemporary organisational functioning of universities are key discussion points. As a result, quality talk in the academia reverberates as a ticking box exercise that meets various stakeholders' demands (e.g., employers, regulatory agencies, students, etc.). In reviewing these corporate ideologies, and how they are applied in the university setting, this article will first situate educational institutions in the business model where students can be seen as customers and/or consumers. By situating educational institutions using a business model, it forces a review of the extant literature. The review culminates in the intersection of higher education, the psychology of learning, marketing, policy analysis, higher education standards, value management and finally disruptive methods. Referencing the literature that positions the student through a variety of lenses as a customer, client, evaluator, partner and/or cocreator of their own knowledge (Alexander, Schallert \& Reynolds 2009; Laing \& Laing 2016; Naidoo \& Jamieson 2005; Ng \& Forbes 2009) and being part of a system (Horine 1994; McGregor 1960; Von Bertalanffy 1972) sheds light into the understanding of the $\underline{\text { students participating in the higher education enterprise. In this paper, we employ a }}$ systematic review of the relevant literature, particularly those related to management ideas that have been pervasive in higher education and the polarising conceptualisations of the student as a customer. We focus on a number of management theories and ideas that have been used in higher education and the debates surrounding the student as customer. Then the article thus proposing possible areas for improvements. Finally, some considerations to actualise these operations are proposed, thus answering the question "What aspects of a business 
model could be used to guide practices in higher education and in particular higher education quality in particular?"

\section{Practices in a business context}

Recent developments in the quality regime are driven by corporatism and neoliberal education (Hicks- 2015). Businesses aim to meet what customers want. This includes creating expectations (need) and fulfilling them. A product can be made to meet what customers want or it can be made to make customers create a need for it (e.g. Davenport et al., 2011). Companies are or have brands and it is important for businesses to maintain strong brand awareness in the public eye (Foroudi-2019; Kim and_\& Kim, 2016). To maintain strong brand presence and reputation companies deliver value to customers or through the various product lines they carry that consumers may or may not associate with the company. Among many other things, brands communicate value, expectations, and benefits to and for the consumer (Brydges \& Hracs 2018; Choi, Ko \& Kim 2016).

Standards are set on products and services to ensure they consistently perform in the way they are intended (Standards Australia-2016). One of the major benefits of doing so is to protect consumers as they encourage innovation, productivity and competition. Standards allow quality to be administered where a product or service can be directly associated with poor quality. A product can be returned, short-lived or defective while a service can be unreliable. Ultimately, however, consumers benefit from products or services that comply with certain set standards. It helps with making informed decisions and their choice. There are aleso both financial and non-financial costs associated with poor quality such as declining profits, loss of customers, contracts or goodwill (Falck, Örtengren \& Högberg 2010; Mahmood et al. 2014; Shetty 1987). These costs are managed or mitigated during the production or service process. 
The awareness of standards and the quality of products or services against such standards have become more accessible worldwide. Take customer reviews for example. The use of the internet and social media allows customer reviews to become ubiquitous thus making it an uncommon practice to not find users' feedback on products or services. Customer reviews can be found in blogs, e-commerce platforms (e.g., Amazon), dedicated product review websites and resellers' websites, right alongside recommendations for similar or related products or services. Communication of value towards a standard, once distributed via the old-fashioned 'word of mouth' is now freely available online (Wright \& Goodwin 1999).

\section{Practices in an educational context}

Universities can be likened to companies that are protective of their brands. A university can appeal to stakeholders in the same way a company can be perceived by the customer. A university's strong brand presence may experience preferential choice for university study thereby raising the rate of enrolment and retention or students' value co-creation (e.g. Foroudi et al., 2019). Its branding can also work for its international recognition as well as in university rankings. University branding influences cross-cultural perceptions and positioning in the global international higher education market (Harvey, 2018; Neumark, 2012).

Whilst there are similarities between product-based organisations and universities in regard to branding and reputation, the conditions in which branding is managed over time or conveyed can be different. University branding may focus on lifelong partnerships with alumni, positioning the university and its role in the region and the communities that it serves, student life, its partnerships with the industry and so on (Harvey, 2018).

In the education setting, the classroom experience cannot be simply likened to any paid service. If so, the higher education sector becomes a marketplace where 'marketisation' 
persists. Naidoo and Jamieson (2005) have also expressed concerns about the commodification of teaching and learning. They relegated the commodification to inflated managerialism, and its associated effects, in universities. Thus, this questions the university's organisational ecology, losing its focus from teaching students to one that is characterised by efficiency, productivity, results, performance, outputs, and key indicators of 'success' measures that are more concrete for business models than being reflective of the learning process (Alexander, Schallert \& Reynolds 2009). This means that the role of universities to prepare students for the future world of work, lifelong learning and global citizenship is no longer the only or true focus of such an institution. This means that such institutions may have additional purposes which require addressing how goals are prioritised.

Drawing on the pervasiveness of technology in classrooms, which have has direct ramifications on the learning process via teaching and learning activities, higher education institutions are rationalising any factors that can assist in bolstering their own competitive advantage (Saunders 2015; Wilson et al. 2007). If higher education institutions focus on business models to produce education, would it be wrong for students to adopt a consumer/customer mindset (Laing \& Laing 2016; Ng \& Forbes 2009)? This mindset has resulted in metaphors reflective of the corporate practices being associated with the student.

\section{Where are students in the business model: customers, consumers, or what?}

University funding processes are structured so that programs are competitively modelled. Understanding that students have a choice in their selections of programs, and ultimately what and how they learn, this fuels the suggestion that they should be considered customers (Alexander, Schallert \& Reynolds 2009; Laing \& Laing 2016). This view helps propagate the "students as customers" stance; thus enabling somewhat of a social movement within university systems. When universities review their funding processes, it is with the intent to 
increase income by managing growth of the organisation (Naidoo \& Jamieson 2005; Ng \& Forbes 2009). Growth is typically seen as an increase in student numbers, which can also be interpreted as an increase in competitively-situated intellectual knowledge streams (Woodall, Hiller \& Resnick 2014a).

As universities are seen as organisations, consumerism models are easily attributed to their existence. This allows for general concerns that such markets need to be established and managed; thus, customers need to be satisfied (Guilbault 2016a). Recruitment and general management processes which draw from marketing principles allow for these key proponents to guide the economic and financial process (Kotler 1991). Therein lies the challenge, as organisations respond to the needs that guide the organisation's growth and as such the corresponding business model needs to be re-engineered towards being more like a learning organisation (Drucker 1988; Senge 1990). Applying business principles to a framework where the outcome of the product is intangible challenges many notions in these contemporary times. Universities once seen as knowledge producers are now seen as knowledge curators with technology infusions as ways to increase, strengthen and create direct causations of learning outcomes (Wilson et al. 2007). Changes in how a learninggenerated product is viewed creates a perceived change in the power of the learning dynamic and also brings to question the ideals associated with the democratisation of education systems (Alexander, Schallert \& Reynolds 2009; Laing \& Laing 2016; McCulloch 2009).

The challenge in understanding the phenomenon of "students as customers" is that customers possess an autonomous power to act throughout the relationship (Laing \& Laing 2016; McCulloch 2009). As we delve one level down from the strategic level into the operational level of the university (i.e., the learning process), the student struggles between being autonomous and having their own agency to engage and perform with and within the process 
(de Alvarez \& Dickson-Deane 2018; Lam 2015; Thompson-Whiteside 2012). If we were to continue this approach, the perceived autonomy is provided to a student literally before the actual enrolment and after the graduation event. The autonomy is a perceived layer which is governed by policies and procedures and it becomes weakened as controls are put in place. These controls guide decisions on how, when and where the learning occurs. For customisation of the system, which is key for competition, there would be a need to identify the areas which are viewed as service-oriented and then illuminate cases or incidences where the customer can have experiences. Douglas, McClelland and Davies (2008a) argue that students' university experience is now largely managed through a controlled mechanism of processes and procedures. Understanding that these empower students as a form of agency to guide the decisions that students can make once they are enrolled in a university, however, it restricts autonomy to a confined boundary within the process. This is not quite a democracy of control but more about allowing for choice within the learning process (Douglas, McClelland \& Davies 2008a; Thompson-Whiteside 2012); thus being consumer-like. As a consumer, the power dynamic shifts to being more open and reactive than a customer who can be proactive in their relationship with the organisation (Tight 2013a; Titus 2008; Woodall, Hiller \& Resnick 2014b). The student decision-making process then begins to emulate a consumer process because of the blurring of the boundaries where control occurs.

\section{Conceptualising a student as a customer?}

The user of a product or service, in business parlance, is a customer, defined sometimes by their tastes, preferences, habits, lifestyle, age group, income and so on. Thus, businesses rely on customers to sustain their activity. Arguably, it is less problematic to define the user as a customer than as a student. Although it can be argued that the student is a 'customer' (Saunders 2015), and many have applied this metaphor in higher education (Guilbault 2016b; 
Koris \& Nokelainen 2015; Tight 2013b), it reduces our perceptions of students. A student who struggles to participate in and engage with the learning experience requires support and assistance, as opposed to an opportunity to purchase a pathway over and around the learning process. By treating students as customers, the learning process is now an economic commodity, and they are reduced to constantly looking for value for money and as economic beings that want to satisfy a particular need. While it can be argued that this student-ascustomer is a reasonable and appropriate metaphor, it does, however, dismiss the fact that they are "learners within" not "purchasers of" an educational experience. They participate in higher education not to buy an experience but to explore, co-create and be co-responsible for such (Alexander, Schallert \& Reynolds 2009; Anderson 1984; Biggs \& Tang 2011; Kirschner \& van Merriënboer 2013). A customer-focused education is dissimilar to a student-focused education; and in this instance, the customer should not be reduced to an object, a patient or a driver for improvement but remain a participant, willing yet challenged in the educational process (Guilbault 2016b; Pitman 2016; Tight 2013b; Watjatrakul 2014).

\section{Challenging the notion}

This is somewhat prosaic of a comparison - students as customers. While it is true that students have expectations (e.g., to learn the things-in a course), these expectations cannot be measured solely on the basis of satisfaction ratings or value received when 'met' (Lomas 2007; Saunders 2015). Educational institutions provide opportunities to explore knowledge using a variety of methods. These methods ensure that all participants in the learning process can build a network of cognitive schema between and with individuals towards the creation of new knowledge (Alexander, Schallert \& Reynolds 2009; Rumelhart 1984; Senge 1990). There is an opportunity for everyone who participates in the learning process to "learn" and through this process, to receive evidence (i.e., certificates/awards, knowledge artefacts, etc.) 
but there is no guarantee of such (Lomas 2007). Equating being a participant (active or not) to be a guaranteed benefactor is the misnomer with what is expected. By dismissing the learning experience as a customer expectation, rather as a student expectation, it can assist in shifting the focus to the student as a learner and not a client or a buyer.

\section{Students as customers and their experience as a quality measure}

While it may be relatively easy to observe improvements in the quality of a product or service, such as better taste or faster delivery times, this is not necessarily true for university programs or subjects, let alone ‘overall university experience' (Edmonds 2007). As mentioned earlier, one familiar measure of satisfaction is student evaluation surveys. Student evaluation surveys are administered in an effort to improve programs and the overall study experience. These improvements can be as little as changing assessments in subjects or as radical as ceasing to offer a course and offering a new one. While students can reasonably assume that their feedback in student evaluation surveys is used to improve programs and subjects, students rarely see the visible improvements (Campbell and $\underline{\&}$ Bozeman 2008; Griffin and $\underline{\&}$ Cook 2009). Knowing how evaluations are used, if at all, for quality assurance may affect their perceptions towards completing evaluation surveys (Kim, Otani and $\underline{\&}$ Cho2013), providing a less reliable data for use in improving programs and subjects.

Quality improvements in a product through feedback can be incompatible with quality improvements in a program or subject due to the differences in the customer as user of a product or service and the student as a learner. While both can provide feedback on their 'experience', it is the translation of improvements that differ in both settings (Campbell et al.-, 2005; Edmonds, 2007). The quality of a tangible product, for example, can be judged using senses or perceptions, whereas an intangible product like education cannot be easily measured by the same approaches used for a product or service (Titus, 2008; Woodall et al., 
2014). Quality improvements in student experience are influenced by a variety of initiatives, often not readily observable, such as improvements in the instructional practices of instructors (Edmonds; 2007) to engage students more effectively in the learning process. Or, initiatives could relate to improving the suite of student services, supporting diversity and inclusion, and increasing student's civic engagement (e.g. see University of Tasmania-2016). These initiatives that can improve student experiences are often not felt within a particular unit or course of study (unlike a commercial product or service) and not measured easily through student evaluations. The student experience is also a learning process where the student is an active participant who co-curates their personal educational experience which is dissimilar to buying a product or service. While students can describe their learning experience, this does not equate to effective pre- and post-delivery comparison of a program or subject.

\section{Standardisation}

The education experience can be made consistent but should not be relegated to just being standardised (i.e. processes kept within a set of guidelines) as it will reduce competitiveness (Klochkov, Papic and $\underline{\&}$ Butkevich, 2017). While standardisation aims to achieve a consistent level of quality, this is less of an easy task in the academy. The delivery of programs provide numerous combinations and permutations of the factors within the delivery model: different lecturers, same course content and different modes of delivery can adhere to standard but each experience will differ thus opposing a Fordism-like (Jorge \& Albagli 2015) product.

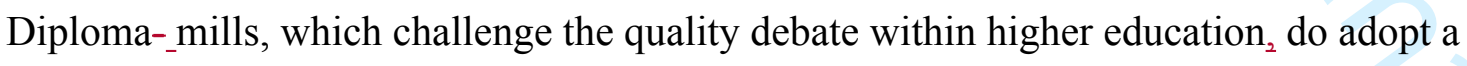
Fordism-like approach but are less reliable in their legalities of what is considered a true educational institution (Noble 1998). 
It was not clear who will set the standards and how they will be determined (ThompsonWhiteside, 2012). As Thomson-Whiteside writes (para. 21),

Teaching and learning standards are set implicitly within the curriculum, the practice of teaching and the expectations of students. Staff with similar disciplinary knowledge interpret these standards and describe the disciplinary values and implicit expectations required of the students. It may be possible to see similar sets of values and standards within the same disciplines across different institutions but to those outside of the discipline group, standard setting is a subjective, tacit and opaque process.

Because standards become more 'opaque' in the academe, it is difficult to compare them with standards associated with products and services. It is extra difficult to determine the quality of teaching, the standards set for this activity and the judgments made against those standards. It is equally challenging to determine the quality of the learning experience, based on standards set for this experience and judgments made to assess such an experience.

Because unlike a product or service, teaching and learning experiences seem impossible to return, refund or exchange if dissatisfaction or 'change of mind' exists. A further example is when standards are demonstrated in the form of learning outcomes. One way to judge the attainment of these learning outcomes is to assess student performance based on specific criteria set against these standards. When these standards are met, it reflects students' ability to demonstrate the associated knowledge, skills, or attitudes that come with the standards.

Standard setting has also pervaded higher education. The standard setting exercises carried out among selected disciplines from various universities reflect the importance of standards in higher education (e.g. in Australia, The creation of Tertiary Education Quality and Standards Authority (TEQSA) and Australian Qualifications Framework (AQF). These are 
created for quality purposes which allows educational organisations to remain internationally competitive and implement a "demand-driven funding model" (Bradley et al., 2008, p.128).

\section{The costs associated with poor quality}

There are also costs associated with poor quality teaching and learning. Either these costs can reflect low retention rates or loss of quality in the workforce and their impact on society. However, these costs are less explicit, at least in quantifiable terms, when compared to the examples above. Customer reviews are an example of conveying experience. The various sources of reviews can be used by customers to help with their choice. Quite often, reviews can either have positive or negative effects on both customer decisions, customer satisfaction and sales (Hsu, Yu and $\underline{\&}$ Chang, 2017; Nga, Carson and $\underline{\&}$ Moore, 2013; Roosen and $\underline{\mathbb{E}}$ Raedts; 2018).

'Customer reviews' are not as varied in regard to university experience. While word of mouth, such as through recommendations from family and friends, can be the same method used for choosing where and what to study, there are not many ways in which to influence future students. This is presumably due to the nature of the 'offer' in universities compared to companies. Education is an intangible and less tacit experience than, say, acquiring a product. Although, lately, websites are or have been established to help students make informed decisions to study, such as the defunct MyUniversity website in the case of Australia; however, websites like these do not necessarily provide detailed consumer feedback and ratings. Rather, they provide information about courses and universities in an aggregated and accessible 'one-stop shop' manner. There are, however, reviews about specific professors such as those collected by ratemyprofessors.com. 
However, by default, companies and universities differ in collecting and sharing reviews about their offerings. This makes the student-as-customer metaphor even more opaque.

\section{Equating $\underline{\underline{s}}$ Student $\underline{\underline{s}} S$ atisfaction to $\underline{\mathbf{c}}$ Customer satisfaction}

One test of meeting customer expectation is satisfying the customer. Often, this is done against pressures to increase market share and reduce costs (Ramadan \& ElMaraghy 2014). When a customer is satisfied, it is likely that they associate a good or service, a brand or a company with good quality. There is potential for repeat purchase, referral or good review; thus, improving the business' ability to depict themselves as satisfying their customers (Alexander 2012; Kuo, Hu \& Yang 2013; Pokryshevskaya \& Antipov 2012). This is one of the fundamental purposes of a business enterprise: keeping customers satisfied.

It comes no surprise that customer relationship management (CRM) theories have been applied to measure student satisfaction in higher education (Ogunnaike, Tairat \& Emmanuel 2014). It has been an important part of university work to gauge student satisfaction in many ways. The most popular of which is course/subject satisfaction surveys. However, these are often used to indicate measures of quality of the student experience (Elliott \& Shin 2002). The more satisfied the students are, the higher the perceived quality. However, while surveys are useful, the quality of a course cannot be measured solely by the student feedback on their own study experience (Al Kuwaiti \& Subbarayalu 2015; Douglas, McClelland \& Davies 2008b; Elliott \& Shin 2002; Kim, Otani \& Cho 2013; Mark 2013). It becomes problematic when these results are used to indicate quality and furthermore, create an inaccurate representation of the measures used for this type of transaction (Elliott \& Shin 2002; Mark 2013). Student evaluation surveys can measure student satisfaction, attitudes and perceptions about a recent course or the range of student support available (Martirosyan 2015) but they do not provide sufficient information about the overall quality of the course. They have also 
been found as unreliable measures of teaching quality (Feistauer \& Richter 2016). Often, their use is associated with assessing teaching competence (Boring, Ottoboni \& Stark 2016; Kelly 2012) inadequate at such (Hornstein 2017), and are beset with a number of issues (Braga, Paccagnella \& Pellizzari 2014; Wright 2006). Student satisfaction is but one "weak" measure for this product as it measures the product before it comes into full fruition - when the knowledge is actually put into practice (Burgess, Senior \& Moores 2018). Thus focussing on satisfaction as a measure to justify quality in this instance is insufficient based on the service provided (Matthews 2018).

\section{Towards some considerations}

Considerations for action begin with a re-conceptualisation of our understanding of quality in higher education. To start, the student-as-customer idea should be evaded because such framing of the discourse around the quality of the service/product and the value attached to quality positions educational institutions will:

- Focus on brand. Universities will focus on their public image in websites, social media, and so on, to promote, improve and protect their brand. They will focus on the emotions and impressions they convey to decision makers, particularly parents and students. They will aim to focus on 'selling points,' including the values espoused and the benefits in choosing their university;

- Focus on growth. Just as companies wish to establish a bigger customer base, one of the approaches of universities for growth would be to establish a large student cohort which will and can equate to a forecast in the dollar revenue; and

- Focus on a unique 'selling the experience' proposition. Universities will focus on making the offer of education as pleasant and appealing as possible with the main focus on students gaining knowledge, skills and abilities. 
In a rather extreme case, academics may be asked to participate in the process of attracting students. Attracting students can be seen as a response to an act of competition and academics could be seen as the key players in attracting students to participate in higher education - a responsibility that is historically not theirs. Funding of academics' salary could change in the future as a result. When students are customers, payment to academics may be likely dependent on the number of students recruited. We have seen current cost-saving mechanisms on the basis of keeping large sizes to meet resource and administration constraints already happening. As a further example o $\ominus$ verload teaching responsibilities could prove cost-effective, for example.

\section{Furthermore, excluding students from the process of accountability [of learning] creates a}

void that Von Bertalanffy (1972), a general systems theorist, would consider irresponsible.

This is because students are part of the system and therefore need to work together with

academics in order for the "product" to be successful. Deming (as cited in Horine, 1994)

would further elaborate that the quality of the system is the true measure of success; thus

catering for all students including both poor performers and those who may be recognised as achieving the ultimate goal (McGregor, 1960). Using these three tenets (i.e., brand, growth and uniqueness) allows educational institutions to build a framework that leverages business models within the context of the values akin to the education system. These tenets are supported by two key positions: the learning experience is not finite and measuring such is time-based.

\section{Students are students, not customers, and the learning experience is not finite}

Tight (2013, p. 26) explains that the 'student as customer' metaphor relates to the university being the provider of products and services (programs and support) and students act as consumers. This metaphor drives change in the university, mostly relating to accountability, 
As a concept, theoretically, satisfaction can be measured in, say, a hypothetical unit of measurement called 'utils' (O'Connor \& Faille 2000). However, learning could be possibly measured using a hypothetical unit of measurement but it is without meaning to the individual student (Nel 2017). As such, it is probably inappropriate to conceptualise students as customers or clients as this refocuses higher education teaching and learning to business activity intended to 'satisfy' the student. It puts an emphasis on treating the student as 'customer is always right' and a redirection of attitudes and beliefs to delivering 'excellent customer service' to the student. This may create an 'entertainer' role rather than a 'facilitator' role for the teacher. This may also reduce quality into measures that objectify the student as a customer (e.g. how satisfied were the students instead of how well they have achieved learning outcomes or how work-ready they were). If at all, students should be partners in learning (Matthews; 2018).

\section{Education quality, which has many measures, is felt later in life}

Lomas (2007) posits that "the student is only able to reflect fully upon the benefits of the knowledge and skills acquired and the attitudes that have been developed after a number of years when there has been sufficient opportunity to realise what they have learnt in a workplace setting (p. 35).” Thus, to measure quality, such as in student evaluations, represents only a short snapshot of the experience. Education quality is not measured in terms 
of the employment gained in return for paying tuition fees or accruing student debt. It is felt later in life as the whole extent of opportunities derived, in both personal and professional ways, out of the educational experience.

Inherently, measuring quality in higher education is challenging $\left(\mathrm{OECD}_{\overline{ }}, 2010\right)$. Measuring teaching quality is challenging. Measuring learning quality is also challenging. It becomes even more problematic when we design instruments that do not measure what they intend to. Measuring quality of research may be doing a far better job at this. Established metrics to measure quality and impact in research are already in place and well-understood internationally. However, measuring teaching and learning quality begins with gradually moving away from the concept of the student as a customer.

\section{Limitations, implications and further research}

This paper can certainly benefit from many other concepts in business that have been applied in higher education, which it lacks. It only focussed on a number of key and popular ideas in management theory that have been used in higher education more broadly. Nonetheless, it offers a rethinking of the quality initiatives of universities to improve the student experience against the backdrop of pressures emanating from practices that influence universities to display more 'corporate-like' behaviour.

There are a number of implications for higher education the discussions above can assist in unpacking. First, it may not matter whether universities treat customers as students or not when talking about quality in higher education. Student-focussed quality initiatives can be devoid of the student as customer concept. How programs, subjects and experiences are curated can be solely for the purpose of continuous improvement, an ongoing commitment within departments and schools to better the student experience, improve learning outcomes, 
or completion and retention rates. Second, universities that choose to treat the student as a customer may find it beneficial to apply a relationship marketing approach to higher education (Hemsley-Brown and Oplatka-2006). This might influence the orientation of services provided to students that have to do with other aspects of their study experience quality such as student accommodation, parking, sports facilities and campus safety. Lastly, those against the student as customer concept may focus on the long-term impact of quality initiatives such as promoting lifelong learning, building long-term relationships with alumni and employers and those that further promote academic integrity.

A further research is to explore the various forms of quality initiatives already in place and the strength of influence management theories have. For example, the extent to which business accreditation (e.g. Association to Advance Collegiate Schools of Business [AACSB] or European Quality Improvement System [EQUIS]) influences the quality processes within a Business School can be explored. Do prescribed accreditation standards inhibit (or promote) creativity and innovation in improving the quality of the teaching, learning and assessment activities within a unit of study or the whole program? Also, how is student experience linked with accreditation or accreditation-driven quality processes? Or, one can look at the peer review frameworks and processes (e.g. academics providing formal feedback to other academics through teaching observations) across a number of universities and examine how these complement student evaluations in measuring teaching competence and, by extension, their impact on student experience. Perhaps a systematic review could do this. Further research can also include a review of existing quality frameworks or processes that have significant influence on teaching quality and the quality of the experience of the learner such as student support and library services and how pervasive management theories are on those frameworks. These investigations may also reveal how nuanced the student as customer 
concept is, and how beneficial for universities it can be such in developing marketing strategy (Guilbault, 2018).

\section{Conclusion}

This paper reviewedexplored some of the issues associated with using some management concepts into higher education. Many of the concepts used in business that were migrated to quality talks in higher education are argued as fundamentally lacking in substance or at least not easily transferable or directly applicable to higher education. They can also be tricky and with potential adverse consequences such as the education experience being simply transactional in nature (Matthews, 2018). It is argued that when the student is referred to as a customer, quality improvements in teaching and learning can be skewed towards satisfying the student-customer, disregarding the real and true value of the educational experience. The focus is in the price of the experience rather than its value.

We argue that some of the underlying concepts in business used in education are not easily transferable, let alone usable. Thus, some considerations have been put forward. These considerations revisit the basic notions of teaching and learning in higher education. It puts an emphasis on sidestepping the student-as-customer metaphor, that learning is not expressed in dollar terms, and that the quality of the student experience cannot be measured by student evaluation alone because it is felt much later in life. There are implications for higher education when moving away from the student-as-customer metaphor. It refocuses education to centre on the student as a learner, an active participant in the learning process and a cocreator of knowledge.

Arguably, in the coming years, the student will remain commoditised as a customer, and perhaps particularly for those higher education institutions whose funding is heavily 
dependent upon course fees. It can be expected that the notions of student as customer will not disappear quickly, and perhaps never will. This may actually be perceived as not problematic. Institutions of higher learning may see this as an opportunity to redesign their offer that mimics a value-for-money approach to business. Their key offer strategy could be answering the student's "What's in it for me?" question, which tries to use 'selling strategies' that focus on the key strengths and value propositions of the offer. As discussed in this article, notions such as this can muddy the true value of the student experience because the implications for higher education could potentially be forgetting that the student is not just a number.

\section{References}

Al Kuwaiti, A. and Subbarayalu, A. V. (2015), “Appraisal of students experience survey (SES) as a measure to manage the quality of higher education in the Kingdom of Saudi Arabia: an institutional study using six sigma model”, Educational Studies, 41 (4), 430-443.

Alexander, P., Schallert, D., \& Reynolds, R. (2009), "What is learning anyway? A topographical perspective considered", Educational Psychologist, 44 (3), 176-192.

Alexander, M.W. (2012), "Delight the Customer: A Predictive Model for Repeat Purchase Behavior”, Journal of Relationship Marketing, 11 (2), 116-123.

Anderson, R. C. (1984), "Role of the reader's schema in comprehension, learning, and memory", Learning to Read in American Schools: Basal Readers and Content Texts, 29, 243-257. 
Biggs, J., \& Tang, C. (2007), “Teaching for quality learning at university”, Society for research into higher education, Retrieved from http://www.citeulike.org/group/4810/article/3680928

Boring, A., Ottoboni, K. and Stark, P. B. (2017), “Student evaluations of teaching (mostly) do not measure teaching effectiveness", ScienceOpen Research, 2016 (01), 1-11.

Bradley, D., Noonan, P., Nugent, H. and Scales, B. (2008), Review of Australian higher education, Canberra, Australia, Department of Education Employment and Workplace Relations.

Braga, M., Paccagnella, M. and Pellizzari, M. (2014), “Evaluating students' evaluations of professors", Economics of Education Review, 41, 71-88.

Brydges, T. and Hracs, B. J. (2018), “Consuming Canada: How fashion firms leverage the landscape to create and communicate brand identities, distinction and values:, Geoforum, 90 (March), 108-118.

Burgess, A., Senior, C., \& Moores, E. (2018), “A 10-year case study on the changing determinants of university student satisfaction in the UK", PLOS ONE, 13 (2), e0192976. https://doi.org/10.1371/journal.pone.0192976

Campbell, J. and Bozeman, W. C. (2008), "The value of student ratings: Perceptions of students, teachers, and administrators", Community College Journal of Research \& Practice, 32, 13-24.

Campbell, H. E., Steiner, S. and Gerdes, K. (2005), "Student evaluations of teaching”, Journal of Public Affairs Education, 11 (3), 211-231. 
Choi, E., Ko, E. and Kim, A. J. (2016), “Explaining and predicting purchase intentions following luxury-fashion brand value co-creation encounters", Journal of Business Research, 69 (12), 5827-5832.

Davenport, T. H., Mule, L. D. and Lucker, J. (2011), “Know what your customers want before they do", Harvard Business Review, 89 (12), 84-92.

de Alvarez, M. S., \& Dickson-Deane, C. (2018), “Avoiding Educational Technology Pitfalls for Inclusion and Equity", TechTrends, 1-9.

Douglas, J., McClelland, R. and Davies, J. (2008), “The development of a conceptual model of student satisfaction with their experience in higher education", Quality Assurance in Education, 16 (1), 19-35.

Drucker, P. E. (1988), “The coming of the new organization”, Harvard Business Review, 4553.

Edmonds, C. (2007), “Continuous quality improvement: integrating best practice into teacher education”, International Journal of Educational Management, 21 (3), 232-237.

Elliott, K. M., \& Shin, D. (2002), “Student Satisfaction: An alternative approach to assessing this important concept", Journal of Higher Education Policy and Management, 24 (2), 197-209. https://doi.org/10.1080/1360080022000013518

Falck, A-C., Örtengren, R. and Högberg, D. (2010) The Impact of Poor Assembly Ergonomics on Product Quality: A Cost-Benefit Analysis in Car Manufacturing”, Human Factors and Ergonomics in Manufacturing, 20 (1), 24-41. 
Feistauer, D. and Richter, T. (2017), “How reliable are students' evaluations of teaching quality? A variance components approach", Assessment \& Evaluation in Higher Education, 42 (8), 1263-1279.

Foroudi, P. (2019), "Influence of brand signature, brand awareness, brand attitude, brand reputation on hotel industry's brand performance", International Journal of Hospitality Management, 76 (Part A), 271-285.

Foroudi, P., Yu, Q., Gupta, S. and Foroudi, M. M. (2019), "Enhancing university brand image and reputation through customer value co-creation behaviour", Technological Forecasting \& Social Change, 138, 218-227.

George, D. (2007), “Market overreach: The student as customer”, The Journal of SocioEconomics, 36, 65-977.

Guilbault, M. (2016), "Students as customers in higher education: reframing the debate", Journal of Marketing For Higher Education, 26 (2), 132-142. doi:10.1080/08841241.2016.1245234

Guilbault, M. (2018), "Students as customers in higher education: The (controversial) debate needs to end", Journal of Retailing and Consumer Services, 40, 295-298.

Griffin, D. and Cook, V. (2009), “Acting on evaluation: Twelve tips from a national conference on student evaluations", Medical Teacher, 31, 101-104.

Guilbault, M. (2016), "Students as customers in higher education: reframing the debate", Journal of Marketing for Higher Education, 26 (2), 132-142. 
Harvey, S. (2018), “University branding: Your clever guide to higher education branding”, Accessed 25 October 2019 from https://fabrikbrands.com/university-branding-and-highereducation-branding/

Hemsley-Brown, J., Oplatka, I., 2006. Universities in a competitive global marketplace: a systematic review of the literature on higher education marketing", International Journal of Public Sector Management, 19 (4), 316-338.

Hicks, D. (2015), “Neoliberal education”, Retrieved November 4, 2015, from http://www.teaching4abetterworld.co.uk/docs/Neoliberal Education.pdf

\section{Horine, J. (1994, March), “' “Improving the Educational System through Deming's Systems} Theory", In The educational forum (Vol. 58, No. 1, pp. 30-35), Taylor \& Francis

\section{Group.}

Hornstein, H. A. (2017), "Student Evaluations of Teaching Are an Inadequate Assessment Tool for Evaluating Faculty Performance", Cogent Education, 4 (1), 1-8.

Hsu, C.-L., Yu, L.-C. and Chang, K.-C. (2017), "Exploring the effects of online customer reviews, regulatory focus, and product type on purchase intention: Perceived justice as a moderator", Computers in Human Behavior, 69 (2017), 335-346.

Jorge, V.D. and Albagli, S. (2015), “The role of information in the area of quality: From fordism to cognitive capitalism”, Transinformacao, 27 (3), 245-253.

Kelly, M. (2012), "Student evaluations of teaching effectiveness: Considerations for Ontario universities", Toronto: Council of Ontario Universities. 
Kim, B.J. , Otani, K. and Cho, J-I. (2013), “Customer Satisfaction Theory in Public Administration Education: Revisiting Student Evaluation of Teaching”, International Journal of Public Administration, 36 (11), 791-797.

Kim, D. K. and Kim, M. (2016), "Influence of Brand Awareness and Brand Attitude on Purchase", Journal of Marketing Thought, 3 (1), 16-26.

Kirschner, P. A., \& van Merriënboer, J. J. (2013), “Do learners really know best?” Urban legends in education. Educational Psychologist, 48 (3), 169-183.

Klochkov, Y., Papic, L. and Butkevich, R. (2017), "Development of the Standardization System in an Organization", International Journal of Reliability, Quality \& Safety Engineering, 24 (6), 1-15.

Koris, R. and Nokelainen, P. (2015), “The Student-Customer Orientation Questionnaire (SCOQ): Application of Customer Metaphor to Higher Education”, International Journal Of Educational Management, 29 (1), 115-138.

Kotler, P. (1991), “Marketing management: Analysis, planning, and control”, Prentice-hall.

Kuo, Y.-F., Hu, T.-L. and Yang, S.-C. (2013), "Effects of inertia and satisfaction in female online shoppers on repeat-purchase intention The moderating roles of word-of-mouth and alternative attraction", Managing Service Quality, 23 (3), 168-187

Laing, C. L., \& Laing, G. K. (2016), “The student-as-customer metaphor: A deconstruction using Foucauldian constructs”, Australasian Accounting, Business and Finance Journal, 10 (1), 40-54. 
Lam, J. Y. (2015), “Autonomy presence in the extended community of inquiry”, International Journal of Continuing Education and Lifelong Learning, 8 (1), 39.

Lomas, L. (2007), “Are students customers? Perceptions of academic staff”, Quality in Higher Education, 13 (1): 31-44.

Mahmood, S., Ahmed, S. M., Panthi, K. and Kureshi, N. I. (2014), "Determining the cost of poor quality and its impact on productivity and profitability", Built Environment Project \& Asset Management, 4 (3), 296-311.

Mark, E. (2013), "Student satisfaction and the customer focus in higher education”, Journal Of Higher Education Policy \& Management, 35 (1), 2-10. doi:10.1080/1360080X.2012.727703

Martirosyan, N. (2015), “An Examination of Factors Contributing to Student Satisfaction in Armenian Higher Education”, International Journal of Educational Management, 29 (2), 177-191.

Matthews, K.E. (2018), "Stop treating students like customers and start working with them as partners in learning”, The Conversation. Retrieved 25 October 2019, from https://theconversation.com/stop-treating-students-like-customers-and-start-workingwith-them-as-partners-in-learning-93276

McCulloch, A. (2009), “The student as co-producer: Learning from public administration about the student-university relationship", Studies in Higher Education, 34 (2), 171183.

\section{McGregor, D. (1960), “Theory X and theory Y”, Organization theory, 358, 374.}


Naidoo, R. and Jamieson, I. (2005), "Knowledge in the marketplace: The global commodification of teaching and learning in higher education”, In P. Ninnes \& M. Hellstén (Eds.), Internationalizing higher education: Critical explorations of pedagogy and policy (pp. 37-52), Hong Kong: Hong Kong University Press.

Nel, L. (2017), "Students as collaborators in creating meaningful learning experiences in technology-enhanced classrooms: An engaged scholarship approach", British Journal of Educational Technology, 48 (5), 1131-1142. https://doi.org/10.1111/bjet.12549

Neumark, V. (2012), "What's in a name? The value of a good university brand", Retrieved 25 October 2019, from https://www.theguardian.com/higher-educationnetwork/blog/2012/apr/03/branding-universities

Ng, I. C., and Forbes, J. (2009), "Education as service: The understanding of university experience through the service logic", Journal of Marketing for Higher Education, 19 (1), 38-64.

Nga N. Ho-Dac, Carson S.J. and Moore, W.L. (2013), "The Effects of Positive and Negative Online Customer Reviews: Do Brand Strength and Category Maturity Matter?”, Journal of Marketing, 77 (6):37-53.

Noble, D. F. (1998). Digital diploma mills: The automation of higher education. Science as Culture, 7 (3), 355-368.

O’Connor, D. E. and Faille, C. (2000), "Basic Economic Principles”, Westport, CT: Greenwood Press. 
Ogunnaike, O., Tairat, B., \& Emmanuel, J. (2014), “Customer relationship management approach and student satisfaction in higher education marketing", Journal of Competitiveness, 6 (3), 49-62.

Organisation for Economic Co-operation and Development (2010), "Learning our lesson: review of quality teaching in higher education", Paris: OECD.

Pitman, T. (2016), “The Evolution of the Student as a Customer in Australian Higher Education: A Policy Perspective”, Australian Educational Researcher, 43 (3), 345 359.

Pokryshevskaya, E. B. and Antipov, E. A. (2012), “The strategic analysis of online customers' repeat purchase intentions", Journal of Targeting, Measurement and Analysis for Marketing, 20 (3), 203-211.

Ramadan, K., and ElMaraghy, W. (2014), "Product Families and Platforms Diversification: Customer Expectations, Product Variations, or Self-competition?", Procedia CIRP, 16(Product Services Systems and Value Creation. Proceedings of the 6th CIRP Conference on Industrial Product-Service Systems), 104-109. doi:10.1016/j.procir.2014.02.003

Roozen, I., and Raedts, M. (2018), “The effects of online customer reviews and managerial responses on travelers' decision-making processes", Journal of Hospitality Marketing \& Management, 27 (8), 973-996.

Rumelhart, D. E. (1984). Schemata and the cognitive system. In R. S. Wyer, Jr. and T. K. Srull (Eds.), Handbook of social cognition, 1, 161-188). Mahwah, NJ, US: Lawrence Erlbaum Associates Publishers. 
Saunders, D. B. (2014), “Exploring a Customer Orientation: Free-Market Logic and College Students", Review Of Higher Education, 37 (2), 197-219.

Saunders, D. B. (2015), “They do not buy it: exploring the extent to which entering first-year students view themselves as customers", Journal Of Marketing For Higher

Education, 25 (1), 5-28. doi:10.1080/08841241.2014.969798

Senge, P. M. (1990), “The fifth discipline: The art and practice of the learning organization”, New York: Currency Doubleday.

Shetty, Y. K. (1987), "Product Quality and Competitive Strategy”, Business Horizons, 30 (3), $46-52$.

Standards Australia (2016), "Benefits of standards", Retrieved 3 February 2016, from http://www.standards.org.au/StandardsDevelopment/What is_a_Standard/Pages/Bene fits-of-Standards.aspx.

Thompson-Whiteside, S. (2012), "Setting standards in Australian higher education", Australasian Association for Institutional Research Journal, 17 (1). Available: http://www.aair.org.au/articles/volume-17-no-1/17-1-setting-standards-in-australianhigher-education

Tight, M. (2013), “Students: customers, clients or pawns?” Higher Education Policy, 26 (3), 291-307.

Titus, J. J. (2008), “Student ratings in a consumerist academy: Leveraging pedagogical control and authority", Sociological Perspectives, 51 (2), 397- 422. 
University of Glasgow (2013), “Academic Quality Framework”, Retrieved 20 March 2017, from http://www.gla.ac.uk/media/media_127773_en.pdf.

University of Tasmania (2016), "Student Experience Strategy (2016-2010)”, Retrieved 25 October 2019, from https://www.utas.edu.au/ data/assets/pdf file/0010/807994/SE$\underline{\text { Strategy-v.6.pdf. }}$

\section{Von Bertalanffy, L. (1972), “The history and status of general systems theory”, Academy of} management journal, 15 (4), 407-426.

Watjatrakul, B. (2014), "Factors affecting students' intentions to study at universities adopting the "student-as-customer" concept", International Journal Of Educational Management, 28 (6), 676-693. doi:10.1108/IJEM-09-2013-0135

Wilson, S., Liber, O., Griffiths, D., \& Johnson, M. (2007, June 25), “Preparing for disruption: Developing institutional capability for decentralized education technologies", 13861395. Retrieved from https://www.learntechlib.org/primary/p/25557/

Woodall, T., Hiller, A. and Resnick, S. (2014), "Making sense of higher education: Students as consumers and the value of the university experience", Studies in Higher Education, 39 (1), 48-67.

Wright, R. E. (2006), "Student evaluations of faculty: Concerns raised in the literature, and possible solutions", College Student Journal, 40, 417-422.

Wright, G., and Goodwin, P. (1999), "Rethinking value elicitation for personal consequential decisions. Journal of Multi-Criteria Decision Analysis, 8 (1), 3-10. 